\title{
Incretin Mimetics and Dipeptidyl Peptidase-4 Inhibitors: Innovative Treatment Therapies for Type 2 Diabetes
}

\begin{abstract}
The prevalence of diabetes and impaired glucose tolerance is predicted to dramatically increase over the next two decades. Clinical therapies for type 2 diabetes mellitus (T2DM) have traditionally included lifestyle modification, oral anti-diabetic agents, and ultimately insulin initiation. In this report, we review the clinical trial results of two innovative T2DM treatment therapies that are based on the glucoregulatory effects of incretin hormones. Incretin mimetics are peptide drugs that mimic several of the actions of glucagon-like peptide-1 (GLP-1) and have been shown to lower glycated hemoglobin (A1C) levels in patients with T2DM. Additionally, incretin mimetics lower postprandial and fasting glucose, suppress elevated glucagon release, and are associated with progressive weight reduction. Dipeptidyl peptidase-4 (DPP-4) inhibitors increase endogenous GLP-1 levels by inhibiting the enzymatic degradation of GLP-1. Clinical studies in patients with T2DM have shown that DPP-4 inhibitors reduce elevated $\mathrm{A} 1 \mathrm{C}$, lower postprandial and fasting glucose, suppress glucagon release, and are weight neutral. Collectively, these new drugs, given in combination with other antidiabetic agents, such as metformin, sulfonylureas, and/or thiazolidinediones, can help restore glucose homeostasis in poorly controlled patients with T2DM. (Arq Bras Endocrinol Metab 2008; 52/6:1039-1049)
\end{abstract}

Keywords: Type 2 diabetes; Exenatide; DPP-4 inhibitor; GLP-1; Incretin

\section{RESUMO}

Incretinomiméticos e Inibidores da Dipeptidil Peptidase-4: Terapias Inovadoras para o Tratamento do Diabetes Tipo 2.

É previsto que a prevalência de diabetes e a intolerância à glicose aumente dramaticamente ao longo das próximas duas décadas. As terapias clínicas para diabetes melito tipo 2 (DM2) têm tradicionalmente incluído modificação do estilo de vida, agentes antidiabéticos orais e, por último, o início da insulina. Neste artigo, revisamos os resultados dos estudos clínicos de duas terapias inovadoras no tratamento do DM2 baseadas nos efeitos glicorregulatórios dos hormônios incretina. Os incretinomiméticos são medicamentos peptídeos que mimetizam várias das ações do peptídeo semelhante ao glucagon-1 (GLP-1) e têm demonstrado reduzir níveis de hemoglobina glicada (A1C) em pacientes com DM2. Adicionalmente, incretinomiméticos reduzem as glicemias pós-prandial e de jejum, suprimem a liberação elevada do glucagon, e são associados com redução de peso. Os inibidores da dipeptidil peptidase-4 (DPP-4) aumentam os níveis de GLP-1 endógeno pela inibição da degradação enzimática do GLP-1. Estudos clínicos em pacientes com DM2 têm demonstrado que inibidores da DPP-4 reduzem A1C elevada, reduzem as glicemias pós-prandial e de jejum, suprimem a liberação elevada do glucagon e são neutros quanto ao peso. Coletivamente, estas novas medicações, administradas em combinação com outros agentes antidiabéticos, como metformina, sulfoniluréias e/ou tiazolidinedionas (TZDs), podem ajudar a recuperar a homeostase glicêmica de pacientes com DM2 não-controlados. (Arq Bras Endocrinol Metab 2008; 52/6:1039-1049)

Descritores: Diabetes tipo 2; Exenatida; Inibidor da DPP-4, GLP-1; Incretina perspectiva

\author{
JAIME A. DAVIDSON \\ ERIKA B. PARENTE \\ JORGE L. GROSS
}

Department of Medicine, Division of Endocrinology, University of Texas Southwestern Medical School, Dallas, TX, USA (JAD); Lilly Research Laboratories, Eli Lilly and Company, Brazil Ltda, São

Paulo, SP, Brazil (EBP);

Serviço de Endocrinologia, Hospital de Clínicas de Porto Alegre, Federal University of Rio Grande do Sul, Porto Alegre, RS, Brazil (JLG).

Recebido em 14/1/2008 Aceito em 20/5/2008 


\section{INTRODUCTION}

A N estimated 64 million people in Latin America and the Caribbean will suffer from diabetes in 2025 (1). The prevalence of diabetes in this world region ranges from $6 \%$ (in Guadeloupe) to $18 \%$ (in Jamaica) and has resulted in an economic burden of $\$ 65$ billion in Latin America and the Caribbean (1). According to estimates from the International Diabetes Federation, approximately 5.6 million people in Brazil alone have diabetes and another 7.5 million have impaired glucose tolerance (2). The diabetes epidemic is largely credited to sedentary lifestyles, obesity and the migration of rural populations to cities (3-8).

Elevated blood glucose is a defining feature of T2DM. The pathogenesis of T2DM includes insulin resistance (9) and progressive $\beta$-cell dysfunction. In the prediabetic state, insulin release increases to compensate for insulin resistance. Progression to impaired glucose tolerance is characterized by declining pancreatic $\beta$-cell function and mass (10-12) and leads to the loss of adequate insulin release. In parallel, postprandial blood glucose control is lost. The excess release of glucagon from abnormally-functioning pancreatic $\alpha$-cells further exacerbates the elevation of blood glucose (13-15) and accelerates $\beta$-cell apoptosis (11). Left untreated, $\beta$-cell function continues to deteriorate and patients progress to impaired fasting glucose and ultimately to T2DM $(16,17)$.

Lifestyle modification and early and aggressive clinical intervention for diabetes patients and those at risk can prevent progression of T2DM (18-21). In the early stages of T2DM, patients are typically treated with a variety of oral anti-diabetic agents (22-24). These clinical therapies include oral drugs that are classified as insulin sensitizers (e.g., biguanides and thiazolidinediones), insulin secretagogues (e.g., sulfonylureas and meglitinides), and $\alpha$-glucosidase inhibitors. Current therapies can improve overall glucose control but most do not effectively target postprandial glycemia. Recent breakthroughs in the understanding of incretin-based therapies have provided options for treating patients with T2D.

The two key incretin hormones that have been identified are glucagon-like peptide-1 (GLP-1) and glucose-dependent inhibitory peptide (GIP). Both peptides are secreted in response to nutrient intake and stimulate glucose-dependent insulin secretion (25). The incretin effect, which has been attributed to
GLP-1 and GIP, is recognized as a significantly greater insulin secretory response to oral glucose compared to intravenous glucose. This effect helps regulate postprandial glucose levels and accounts for $60 \%$ of insulin secretion in response to an oral glucose load (26). Since the insulinotropic activity of GLP-1, not GIP, is preserved in patients with T2DM, GLP-1 has been considered as a potential treatment for these patients (27).

GLP-1 is a multifunctional hormone which also inhibits glucagon secretion, slows gastric emptying and functions as a regulator of satiety (28-34). Although not demonstrated in humans, experimental in vivo and in vitro studies have reported that GLP-1 promotes $\beta$-cell proliferation and function, induces islet neogenesis and reduces apoptosis $(35 ; 36)$. Despite GLP-1's possible proliferative and anti-apoptotic effects on $\beta$-cells, its therapeutic potential is limited by its short half-life ( $\sim 2$ minutes) as it is rapidly degraded by the endogenous protease, DPP-4 (37-39). Consequently, incretin mimetics, peptides that mimic several of the glucoregulatory actions of GLP-1 but are resistant to degradation by DPP-4, continue to be investigated for the treatment of patients with T2DM. A second strategy has focused on developing inhibitors of the DPP-4 enzyme, which increases endogenous GLP-1 levels $(24,40)$. Here we review the clinical findings of three approved incretin-based T2DM therapies; specifically the incretin mimetic, exenatide and two DPP-4 inhibitors, sitagliptin and vildagliptin.

\section{INCRETIN MIMETIC-EXENATIDE}

Exenatide (Amylin Pharmaceuticals, Inc. and Eli Lilly and Company) is a 39 -amino acid peptide incretin mimetic, currently available for the treatment of patients with T2DM in many countries including the United States, the European Union (EU) and parts of Latin America. It is a synthetic form of exendin-4 and although it shares $50 \%$ amino acid sequence identity with human GLP-1, these two peptides are transcribed from separate genes (41). Exenatide is injected twice a day, daily ( 5 or $10 \mathrm{mcg}$ ) within 1 hour before the two main meals of the day (approximately 6 hours or more apart) and has multiple glucoregulatory modes of actions, many of which are similar to those of endogenous GLP-1 (Table 1). 
Table 1. Modes of action of incretin mimetics and DPP-4 Inhibitors $(29,42,43)$.

\begin{tabular}{|c|c|c|c|}
\hline Characteristic of type 2 diabetes & Biological action of antidiabetes agent & Incretin mimetics & DPP-4 inhibitors \\
\hline $\begin{array}{l}\text { Defective glucose-stimulated insulin } \\
\text { secretion }\end{array}$ & $\begin{array}{l}\text { Increases glucose-dependent insulin } \\
\text { secretion }\end{array}$ & Yes & Yes \\
\hline $\begin{array}{l}\text { Inappropriately elevated hepatic } \\
\text { glucose production }\end{array}$ & Decreases hepatic glucose production & Yes & Yes \\
\hline Hyperglucagonemia & $\begin{array}{l}\text { Suppresses inappropriately elevated } \\
\text { postprandial glucagon secretion }\end{array}$ & Yes & Yes \\
\hline Accelerated gastric emptying & Slows gastric emptying & Yes & Marginal \\
\hline Increased food intake & Decreases food intake & Yes & No \\
\hline Lack of biphasic secretory response & $\begin{array}{l}\text { Restores biphasic insulin secretory } \\
\text { response }\end{array}$ & Yes & Unknown \\
\hline $\begin{array}{l}\text { Reduced pancreatic beta-cell mass } \\
\text { and insulin content }\end{array}$ & $\begin{array}{c}\text { Increases beta-cell mass and improves } \\
\text { beta-cell function (reported in animal } \\
\text { studies) }\end{array}$ & Yes & Yes \\
\hline Reduced insulin sensitivity & Enhances insulin sensitivity & No & No \\
\hline Obesity & Weight reduction & Yes & No \\
\hline
\end{tabular}

\section{EXENATIDE CLINICAL TRIALS IN PATIENTS WITH T2DM}

Key primary and secondary efficacy results from three placebo-controlled developmental trials, exenatide in combination with metformin (44), a sulfonylurea (45), or both $(46)$, are given in Table 2 . In these clinical trials, patients with T2DM were given $5 \mathrm{mcg}$ of exenatide twice a day, daily for 4 weeks and 10 mcg thereafter. Participants did not receive additional dietary instruction and exercise counseling. Exenatide treatment $(10 \mathrm{mcg})$ resulted in significant mean $\mathrm{AlC}$ reductions from baseline ranging from $-0.77 \%$ to $-0.86 \%$. Patients also had statistically significant reductions in mean body weight from baseline $(-1.6 \mathrm{~kg}$ to $-2.8 \mathrm{~kg})$. Sustained reduction in mean AlC $(-1.0 \%)$ and progressive body weight loss $(-5.3 \mathrm{~kg})$ have also been observed in patients $(n=217)$ that took part in the subsequent 3 year open-label extensions of the original 30 -week placebo-controlled trials (47).

The effects of exenatide added to a TZD (rosiglitazone or pioglitazone) with or without metformin in T2DM patients has also been investigated (48) (see Table 2). In a 16-week placebo-controlled trial, AlC was reduced $0.89 \%$ from baseline in patients taking exenatide with a TZD compared with an increase of $0.09 \%$ in the control group. Patients treated with exenatide and a TZD lost $1.8 \mathrm{~kg}$ over 16 weeks compared to a $-0.2 \mathrm{~kg}$ reduction in the control group. Glycemic control com- pared with starter insulin therapies (insulin glargine, IG; biphasic insulin aspart, BIA) has also been studied in separate open-label, randomized, controlled, noninferiority trials $(49,50)$. Patients received insulin or exenatide added to maximal effective doses of metformin and a sulfonylurea. IG was titrated to maintain fasting glucose levels of less than $100 \mathrm{mg} / \mathrm{dL}$, while in the BIA trial, insulin doses were adjusted to achieve an optimal balance between glycemic control and risk of hypoglycemia as dictated by the best clinical practice. Reductions in AlC from baseline of approximately $1.1 \%$ were observed in both treatment groups after 26 weeks in the IG trial (49). In the BIA trial (50), patients achieved similar reductions in AlC (exenatide, $-1.04 \%$; BIA, $-0.89 \%$ ) after 52 weeks. In contrast to the non-inferiority observed with regard to AlC reductions, exenatide therapy significantly reduced mean body weight (IG trial, $-2.3 \mathrm{~kg}$; BIA trial, $-2.5 \mathrm{~kg}$ ) compared with weight gain in the insulin groups (IG trial, $+1.8 \mathrm{~kg}$; BIA trial, $+2.9 \mathrm{~kg}$ ). Key efficacy measures for exenatide are summarized for each trial in Table 2 along with baseline clinical characteristics.

The most common adverse events associated with exenatide therapy have been gastrointestinal in nature (eg, nausea, vomiting, and diarrhea) and therefore exenatide use is not recommended in patients with severe gastrointestinal disease. Nausea of mostly mild-to-moderate severity was reported in $33 \%$ to $57 \%$ of exenatide-treated patients across clinical trials summarized in 
Table 2. Summary of clinical trials of $10 \mathrm{mcg}$ exenatide (twice-daily).

\begin{tabular}{|c|c|c|c|c|c|c|}
\hline Reference & $\begin{array}{c}\text { Baseline: } \\
\text { A1C (\%) } \\
\text { Body Weight }(\mathrm{kg}) \\
\text { BMI }\left(\mathrm{kg} / \mathrm{m}^{2}\right)\end{array}$ & $\begin{array}{c}\text { Diabetes } \\
\text { duration }(y)\end{array}$ & $\begin{array}{c}\text { Change from } \\
\text { baseline } \\
\text { A1C (\%) }\end{array}$ & $\begin{array}{c}\text { Percentage of } \\
\text { patients } \\
\text { achieving target } \\
\text { A1C } \leq 7 \%\end{array}$ & $\begin{array}{l}\text { Change from } \\
\text { baseline fasting } \\
\text { glucose (mg/dL) }\end{array}$ & $\begin{array}{l}\text { Change from } \\
\text { baseline body } \\
\text { weight (kg) }\end{array}$ \\
\hline Buse e cols., (45) & $\begin{array}{l}8.6 \\
95 \\
33\end{array}$ & 6.6 & -0.86 & $34 \%$ & -10.8 & -1.6 \\
\hline DeFronzo e cols., (44) & $\begin{array}{c}8.2 \\
101 \\
34\end{array}$ & 4.9 & -0.78 & $40 \%$ & -10.8 & -2.8 \\
\hline Kendall e cols., (46) & $\begin{array}{l}8.5 \\
98 \\
34\end{array}$ & 8.7 & -0.77 & $30 \%$ & -10.8 & -1.6 \\
\hline Heine e cols., (49)* & $\begin{array}{l}8.2 \\
88 \\
31\end{array}$ & 9.9 & -1.11 & $46 \%$ & -25.7 & -2.3 \\
\hline Nauck e cols. 50)* & $\begin{array}{l}8.6 \\
86 \\
31\end{array}$ & 9.8 & -1.04 & $32 \%$ & -32.4 & -2.5 \\
\hline Zinman e cols., 48)* & $\begin{array}{l}7.9 \\
98 \\
34\end{array}$ & 7.3 & -0.89 & $62 \%$ ** & -28.6 & -1.8 \\
\hline
\end{tabular}

* 5 mcg twice-daily for 4-week, 10 mcg twice-daily thereafter; ** Per protocol population; Glucose values were converted from mmol to mg/dL (conversion factor 0.05551).

Table 2. Escalating the dose of exenatide from $5 \mathrm{mcg}$ to $10 \mathrm{mcg}$ after 4 weeks led to a transient increase in nausea which diminished with continued exposure to the higher dose. Severe nausea was uncommon and data from open label extension trials $(51)$ have not shown a significant correlation between nausea and the progressive weight loss observed in patients receiving exenatide therapy. In the oral anti-diabetic agent trials (44-46,48), the overall incidence of hypoglycemia for exenatide and the control groups ranged from 5-36\% and $3-13 \%$, respectively. In the insulin comparator trials $(49,50)$; the overall rates were similar across the treatment groups (exenatide, range $4.7-7.3$ events/patient-year; insulin, range 5.6-6.3 events/patient-year). Across all clinical trials, hypoglycemia was reported most commonly in combination with a sulfonylurea and for this reason a reduction in the dosage of sulfonylurea should be considered when initiating exenatide therapy.

Pre- and post-meal glucose levels were assessed by 7-point self monitored blood glucose (SMBG) profiles in the TZD add-on (48) and insulin comparator trials $(49,50)$. In the TZD add-on trial, significant reductions from baseline were observed at all SMBG time points in the exenatide group while the placebo group showed little change. Although in both insulin comparator trials patients receiving insulin generally had lower endpoint glucose levels before meals, those receiving exenatide had significantly lower 2 -hour postprandial glucose levels following the morning $(p<0.001)$ and evening meals $(p<0.001)$. In these same three trials, pancreatic $\beta$-cell function changes were estimated by homeostasis model assessment (HOMA- $\beta$ ). In those subjects treated with exenatide, HOMA- $\beta$ increased $19 \%$ from baseline, compared with a $6 \%$ decrease with TZD plus placebo (between-group, $\mathrm{p}=0.005$ ). Exenatide was also associated with a $19 \%$ increase in HOMA- $\beta$ (baseline to endpoint change, $\mathrm{p}<0.001$ ) in the BIA comparator trial.

Few significant baseline-to-endpoint changes in fasting lipid parameters were reported in the clinical trials summarized in Table 2. However, the open-label extension trials $(47,51)$ have shown subsequent baseline-to-endpoint improvements in fasting lipids (see Table 3). Twice-daily exenatide given for 3.5 years (completer analysis, $\mathrm{n}=15 \mathrm{l}$ ) was also associated with significant lowering of systolic $(-3.5 \mathrm{mmHg})$ and diastolic blood pressure $(-3.3 \mathrm{mmHg})(47)$. 
Table 3. Summary of baseline to endpoint changes in fasting lipids

\begin{tabular}{|c|c|c|c|c|}
\hline & Total Cholesterol & LDL-C & Triglycerides & HDL-C \\
\hline Sitagliptin (100mg once-daily) & Mean \% Change & Mean \% Change & Mean \% Change & Mean \% Change \\
\hline $\begin{array}{l}\text { Scott e cols., }(52)^{*} \\
\text { Monotherapy }\end{array}$ & $+3.4 \%$ & $+5.5 \%$ & $+3.6 \%$ & $+4.6 \%$ \\
\hline $\begin{array}{l}\text { Rosenstock e cols., (53) } \\
\text { TZD Add-on }\end{array}$ & $+1.6 \%$ & $+5.8 \%$ & $+1.1 \%$ & $+0.6 \%$ \\
\hline $\begin{array}{l}\text { Charbonnel e cols., (54) } \\
\text { Metformin Add-on }\end{array}$ & $+1.9 \%$ & $+3.3 \%$ & $+7.7 \%$ & $+1.3 \%$ \\
\hline Vildagliptin (100mg once-daily) & Mean \% Change & Mean \% Change & Mean \% Change & Mean \% Change \\
\hline $\begin{array}{l}\text { Bosi e cols., (55) } \\
\text { Metformin Add-on }\end{array}$ & Decrease $<3 \%$ & Increase $<3 \%$ & Increase $\sim 5 \%$ & Increase < $1 \%$ \\
\hline $\begin{array}{l}\text { Rosenstock e cols., (56) } \\
\text { TZD Add-on }\end{array}$ & $-3.1 \%$ & $-1.4 \%$ & $-18.1 \%$ & $+12.1 \%$ \\
\hline $\begin{array}{l}\text { Fonseca e cols., (57)* } \\
\text { Insulin Add-on }\end{array}$ & Changed $<4 \%$ & Changed $<4 \%$ & Changed $<4 \%$ & Changed $<4 \%$ \\
\hline $\begin{array}{l}\text { Schweizer e cols. (58) } \\
\text { Metformin Comparator }\end{array}$ & $--2.4 \%$ & $-2.8 \%$ & $+5.3 \%$ & $+2.6 \%$ \\
\hline Exentide (10mcg twice-daily) & $\begin{array}{l}\text { Mean Change } \\
(\mathrm{mg} / \mathrm{dL})\end{array}$ & $\begin{array}{l}\text { Mean Change } \\
(\mathrm{mg} / \mathrm{dL})\end{array}$ & $\begin{array}{l}\text { Mean Change } \\
(\mathrm{mg} / \mathrm{dL})\end{array}$ & $\begin{array}{l}\text { Mean Change } \\
\quad(\mathrm{mg} / \mathrm{dL})\end{array}$ \\
\hline $\begin{array}{l}\text { Blonde e cols., (51) } \\
\text { 82-week Open-label Extension }\end{array}$ & -2.4 & -1.6 & -38.6 & +4.6 \\
\hline $\begin{array}{l}\text { Klonoff e cols., (47) } \\
\text { 3.5-year Open-label Extension }\end{array}$ & -10.8 & -11.8 & -44.4 & +8.5 \\
\hline
\end{tabular}

*These trials used a sitagliptin dose of 50mg twice-daily.

\section{DPP-4 INHIBITORS}

Two DPP-4 inhibitors, sitagliptin and vildagliptin, have been approved for the treatment of T2DM. The two approved DPP-4 inhibitors have multiple glucoregulatory modes of actions, some of which are similar to exenatide (Table 1); however, the lack of effect of DPP-4 inhibitors on gastric emptying and body weight are notable differences. Sitagliptin and vildagliptin inhibit the rapid degradation of GLP-1 by the ubiquitous DPP-4 protease. Other DPP-4 substrates include GIP, GLP-2, pituitary adenylate cyclase-activating polypeptide, neuropeptide $Y$, peptide $Y Y$, substance $P$, and growth releasing hormone (39). These orally active DPP-4 inhibitors increase GLP-1 endogenous levels and lower elevated blood glucose.

\section{SITAGLIPTIN}

Sitagliptin (MK-0431, Merck \& Company) was the first DPP-4 inhibitor approved for the T2DM treatment as adjunctive therapy to diet and exercise. Sitagliptin is approved to be used in 42 countries around the world including the EU, the United States, and parts of Latin America including Brazil and Mexico. The recommended dose of once-daily oral sitagliptin is $100 \mathrm{mg}$. At this dose, sitagliptin can inhibit $\sim 80 \%$ of endogenous DPP-4 activity over a 24-hour period (59). At doses of $12.5 \mathrm{mg}$ or higher, sitagliptin is associated with a 2 -fold increase in active total GLP-1 levels (59).

Clinical trial results of sitagliptin given alone or in combination with oral anti-diabetic agents are summarized in Table 4. Most trials were designed as short term studies (12 to 24 weeks) with similar characteristics, including diet and exercise counseling for patients and wash-out periods of oral anti-diabetic therapy and dose stabilization periods ranging from 6 to 19 weeks. In the monotherapy trials, sitagliptin therapy compared to placebo resulted in statistically significant improvements in $\mathrm{AlC}$ and fasting glucose (52,60-62). Similar reductions from baseline in 2-hour PPG values were observed in these trials $(-41.4 \mathrm{mg} / \mathrm{dL}$ to $-48.6 \mathrm{mg} / \mathrm{dL})(61,62)$. Si- 
tagliptin given as add-on therapy to metformin (54) resulted in similar AlC and fasting glucose reductions as in the monotherapy trials (Table 4). However, there was a more pronounced 2-hour PPG reduction (-61.3mg/ $\mathrm{dL}$ ) in this trial (54), which may be due partly to metformin acting as a weak DPP-4 inhibitor (64).

In a similarly designed trial, the efficacy of sitagliptin as add-on therapy to a TZD was assessed in patients with T2DM (53). In this 24 -week trial patients were treated with pioglitazone ( 30 or $45 \mathrm{mg} /$ day) and sitagliptin or pioglitazone and placebo. Significantly greater baseline to endpoint reductions in mean $\mathrm{AlC}$ and fasting glucose (between-treatment differences of $-0.7 \%$ and $-17.7 \mathrm{mg} / \mathrm{dL}$, respectively) were observed in patients treated with sitagliptin and pioglitazone versus the control group. The non-inferiority of sitagliptin versus glipizide added to metformin therapy $(\geq 1500$ $\mathrm{mg}$ ) was investigated in a 52 -week clinical trial (63). Reductions from baseline in AlC and fasting glucose were similar with sitagliptin and glipizide, demonstrating non-inferiority (63).
Increases in HOMA- $\beta$ ranging from $4 \%$ to $20 \%$ have been shown in the sitagliptin trials. Limited to modest baseline to endpoint improvements in fasting lipids ( $\mathrm{Ta}$ ble 3) were reported in patients treated with sitagliptin alone, or in combination with metformin or pioglitazone (52-54). Sitagliptin therapy has been shown to be weight neutral in all clinical trials except in one study in which sitagliptin given with metformin resulted in weight reduction of $1.5 \mathrm{~kg}$ after 52 weeks of treatment (63). In the clinical trials summarized in Table 4, gastrointestinal adverse events occurred in $12 \%$ to $21 \%$ of patients and were generally mild-to-moderate in severity $(53,54,60-63)$. Other adverse events reported in patients $(>3 \%)$ taking sitagliptin included upper respiratory tract infection, nasopharyngitis and headache (53,54,61-63). The incidence of hypoglycemia was low in these trials $(<2 \%)$ and was similar to the placebo/control arms. Dose reduction of sitagliptin has been recommended for patients with moderate or severe renal insufficiency or end-stage renal disease (65). However, overall, sitagliptin was generally well-tolerated.

Table 4. Summary of clinical trial results for $100 \mathrm{mg}$ once-daily sitagliptin.

\begin{tabular}{|c|c|c|c|c|c|c|}
\hline Reference & $\begin{array}{l}\text { Baseline: } \\
\text { A1C }(\%) \text { body } \\
\text { weight }(\mathrm{kg}) \\
\text { BMI }\left(\mathrm{kg} / \mathrm{m}^{2}\right)\end{array}$ & $\begin{array}{c}\text { Diabetes } \\
\text { duration }(y)\end{array}$ & $\begin{array}{c}\text { Change from } \\
\text { baseline AIC } \\
\text { (\%) }\end{array}$ & $\begin{array}{c}\text { Percentage of } \\
\text { patients achieving } \\
\text { target } \mathrm{A} 1 \mathrm{C} \leq 7 \%\end{array}$ & $\begin{array}{l}\text { Change from } \\
\text { baseline fasting } \\
\text { glucose } \\
\text { (mg/dL) }\end{array}$ & $\begin{array}{l}\text { Change from } \\
\text { baseline body } \\
\text { weight (kg) }\end{array}$ \\
\hline Scott e cols. (52)* & $\begin{array}{c}7.8 \\
\text { NR } \\
30.4\end{array}$ & 4.2 & -0.54 & NR & -18.2 & Neutral \\
\hline Nonaka e cols. (60) & $\begin{array}{l}7.5 \\
\text { NR } \\
25.2\end{array}$ & 4.0 & -0.65 & $58 \%$ & -22.5 & Neutral \\
\hline Raz e cols. (61) & $\begin{array}{c}8.0 \\
89.7 \\
31.8\end{array}$ & 4.5 & -0.48 & $36 \%$ & -12.6 & Neutral \\
\hline Aschner e cols. (62) & $\begin{array}{c}8.0 \\
85 \\
30.3\end{array}$ & 4.3 & -0.61 & $41 \%$ & -12.6 & Neutral \\
\hline Charbonnel e cols. (54) & $\begin{array}{c}8.0 \\
86.7 \\
30.9\end{array}$ & 6.0 & -0.67 & $47 \%$ & -16.2 & Neutral \\
\hline Rosenstock e cols. (53) & $\begin{array}{c}8.1 \\
90.9 \\
32\end{array}$ & 6.1 & -0.85 & $45 \%$ & -16.7 & +1.8 \\
\hline Nauck e cols. (63)** & $\begin{array}{c}7.5 \\
89.5 \\
31.2\end{array}$ & 6.5 & -0.67 & $63 \%$ & -10.1 & -1.5 \\
\hline
\end{tabular}

*Scott e cols. (2007) used a sitagliptin dose of $50 \mathrm{mg}$ twice-daily; ** Per protocol population; NR = not reported; glucose values were converted from mmol to mg/dL (conversion factor 0.05551) (52). 


\section{VILDAGLIPTIN}

Vildagliptin (LAF237, Novartis Pharmaceuticals), another oral treatment developed for the treatment of T2DM, also acts by inhibiting circulating DPP- 4 activity. It is available in Brazil and Mexico as both a $50 \mathrm{mg}$ and $100 \mathrm{mg}$ daily dose and at the publication of this review, had been approved for use in the European Union (EU), recommended as a $50 \mathrm{mg}$ once-daily dose with a sulfonylurea or as $50 \mathrm{mg}$ twice-daily in combina- tion with either metformin or a TZD. Vildagliptin has been studied as a monotherapy (66-69) in combination with other oral antidiabetic agents $(55-57,70,71)$, and against active comparator therapies including TZDs (72) and metformin (58). The maximum daily dose used in clinical trials of vildagliptin was $100 \mathrm{mg}$ (oncedaily or $50 \mathrm{mg}$ twice-daily); other lower doses regimens were also investigated. In this review we present clinical results on the highest dose regimens reported in each of the clinical trials (Table 5).

Table 5. Summary of clinical trial results for $100 \mathrm{mg}$ once-daily vildagliptin.

\begin{tabular}{|c|c|c|c|c|c|c|}
\hline Reference & $\begin{array}{c}\text { Baseline: } \\
\text { A1C (\%) } \\
\text { Body weight }(\mathrm{kg}) \\
\text { BMI }\left(\mathrm{kg} / \mathrm{m}^{2}\right)\end{array}$ & $\begin{array}{c}\text { Diabetes } \\
\text { duration }(y)\end{array}$ & $\begin{array}{c}\text { Change from } \\
\text { baseline A1C } \\
\text { (\%) }\end{array}$ & $\begin{array}{c}\text { Percentage of } \\
\text { patients } \\
\text { achieving } \\
\text { target } A 1 C<7 \%\end{array}$ & $\begin{array}{l}\text { Change from } \\
\text { baseline fasting } \\
\text { glucose } \\
\text { (mg/dL) }\end{array}$ & $\begin{array}{l}\text { Change from } \\
\text { baseline } \\
\text { body weight } \\
\text { (kg) }\end{array}$ \\
\hline Ristic e cols. (69) & $\begin{array}{l}7.6 \\
92 \\
31\end{array}$ & 3.0 & -0.53 & $46 \%$ & -17.1 & -0.07 \\
\hline Pratley e cols. (68)* & $\begin{array}{l}8.0 \\
N R \\
30\end{array}$ & 4.6 & -0.6 & NR & -16.2 & NR \\
\hline Pi-Sunyer e cols. (67) & $\begin{array}{l}8.3 \\
91 \\
32\end{array}$ & 2.1 & -0.8 & $39 \%$ & -19.8 & -0.4 \\
\hline Dejager e cols. (66) & $\begin{array}{c}8.4 \\
92-94 \\
32\end{array}$ & 2.4 & -0.9 & NR & -14.4 & -0.8 \\
\hline Ahren e cols. (70)* & $\begin{array}{l}7.7 \\
N R \\
29\end{array}$ & 5.6 & -0.6 & $\begin{array}{c}42 \% \text { (after } 52 \\
\text { weeks) }\end{array}$ & -18.0 & -0.4 \\
\hline Bosi e cols. (55) & $\begin{array}{l}8.4 \\
95 \\
33\end{array}$ & 5.8 & -0.9 & $\begin{array}{c}54 \% \\
\text { (For patients } \\
\text { with baseline } \\
\text { AlC } \leq 7.9 \text { ) }\end{array}$ & NR & +0.2 \\
\hline Garber e cols. (71) & $\begin{array}{l}8.7 \\
N R \\
32\end{array}$ & 4.6 & -1.0 & $36 \%$ & -19.8 & NR \\
\hline Rosenstock e cols. (56) & $\begin{array}{l}8.8 \\
82 \\
30\end{array}$ & 2.0 & -1.9 & $65 \%$ & -50.4 & +2.1 \\
\hline Fonseca e cols. (57)* & $\begin{array}{l}8.4 \\
95 \\
33\end{array}$ & 14.4 & -0.5 & NR & -14.4 & +1.3 \\
\hline Rosenstock e cols. (72) & $\begin{array}{l}8.7 \\
91 \\
32\end{array}$ & 2.3 & -1.1 & NR & -23.4 & -0.3 \\
\hline Schweizer e cols. (58) & $\begin{array}{l}8.7 \\
91 \\
32\end{array}$ & 1.0 & -1.0 & $35 \%$ & -16.2 & +0.3 \\
\hline
\end{tabular}

*These trials used doses other than $100 \mathrm{mg}$ once-daily; NR = not reported; Glucose values were converted from $\mathrm{mmol}$ to $\mathrm{mg} / \mathrm{dL}$ (conversion factor 0.05551 ). 
In placebo-controlled trials, vildagliptin monotherapy reduced $\mathrm{AlC}$ (range $0.5 \%$ to $0.9 \%$ ) and fasting glucose $(14.4 \mathrm{mg} / \mathrm{dL}$ to $19.8 \mathrm{mg} / \mathrm{dL})$ from baseline. The AlC reductions observed with monotherapy were statistically significantly greater than placebo in all trials. Vildagliptin was studied as add-on therapy to several anti-diabetic agents including insulin, metformin and TZDs. AlC and fasting glucose reductions from baseline ranged from $-0.5 \%$ to $-1.9 \%$ and $-14.4 \mathrm{mg} / \mathrm{dL}$ to $-50.4 \mathrm{mg} / \mathrm{dL}$, respectively, with the greatest changes observed in a subgroup of patients given vildagliptin combined with pioglitazone ( $100 / 30 \mathrm{mg}$ daily). In studies of vildagliptin with active comparator therapies, $\mathrm{AlC}$ and fasting glucose reductions from baseline ranged from $-1.0 \%$ to $-1.1 \%$ and $-16.2 \mathrm{mg} / \mathrm{dL}$ to $-23.4 \mathrm{mg} / \mathrm{dL}$, respectively.

Estimates of $\beta$-cell function and mealtime glucose levels were derived from standard meal challenges performed in monotherapy and add-on trials. Meal challenge tests were performed in two monotherapy trials. In one of the monotherapy trials (68), the mean 4-hour prandial glucose level was statistically significantly reduced $(-34.2 \mathrm{mg} / \mathrm{dL}$ vs. placebo $)$ in the vildagliptin (25mg twice-daily) group. Meal tests were performed in four out of five of the add-on trials; dissimilar methodologies were used to assess mealtime glucose levels. Ahren e cols. (70) reported a statistically significant reduction in the mean 4-hour prandial glucose level $(-39.6 \mathrm{mg} / \mathrm{dL}$ vs. placebo $)$ in the vildagliptin $(25 \mathrm{mg}$ twice-daily plus metformin) group. Greater reductions in 2-hour postprandial glucose levels were observed with vildagliptin compared with placebo in two other add-on trials, one with metformin (55) the other with a TZD (71). Finally, Rosenstock e cols. (56) reported a significant reduction in the peak prandial glucose excursion in the vildagliptin plus TZD group, both baseline to endpoint $(-36.0 \mathrm{mg} / \mathrm{dL})$ and compared with the placebo plus TZD group.

Vildagliptin therapy was associated with an increase HOMA- $\beta$ ( $11 \%$ and $23 \%$ ) in two monotherapy trials $(68,69)$, but improvement relative to placebo was only observed in one trial (69). In three of the add-on trials $(55,56,71), \beta$-cell function was defined by the ratio of insulin secretory rate AUC to glucose AUC. This assessment was statistically significantly increased in two of the $100 \mathrm{mg}$ vildagliptin groups at endpoint $(56,56)$, and also improved more than control in two trials $(55,71)$. Ahren e cols. (70) also demonstrated an association between vildagliptin therapy and improved $\beta$-cell function using a different estimate, the corrected insulin response at peak glucose.

Limited to modest baseline to endpoint improvements in fasting lipids (Table 3 ) were reported in patients treated with vildagliptin alone, or in combination with metformin, TZDs or insulin. Significant improvements in total cholesterol and LDL-C relative to control groups were more commonly reported. Monotherapy (50mg twice-daily) was associated with a $4.5 \%$ decrease in total cholesterol vs. placebo (66). Vildagliptin added to TZD was associated with a $5.6 \%$ decrease in total cholesterol vs. TZD alone and a $10.5 \%$ decrease in LDL-C vs. TZD alone (56). Added to insulin, vildagliptin decreased total cholesterol and LDL-C, $4.0 \%$ and $5.8 \%$ vs. insulin alone, respectively (57). The largest improvements relative to control were observed in an active comparator trial with rosiglitazone. Relative to rosiglitazone, vildagliptin decreased total cholesterol and LDLC by $14 \%$ and $16 \%$, respectively $(72)$.

Vildagliptin therapy has been shown to have little effect on weight in most clinical trials to date with the exception of two studies. Given with a TZD, this therapy resulted in weight gain of $2.1 \mathrm{~kg}(56)$, and given with insulin resulted in weight gain of $1.3 \mathrm{~kg}(57)$, both after 24 weeks of treatment.

Overall, vildagliptin was generally well-tolerated. In the clinical trials summarized in Table 5 , gastrointestinal adverse events were reported in $1 \%$ to $22 \%$ of patients and were generally mild-to-moderate in severity. Gastrointestinal adverse events were not reported in four trials $(56-58,70)$. Other adverse events commonly reported in patients taking monotherapy or in combination with other antidiabetic therapies included headache, nasopharyngitis, dizziness, and upper respiratory tract infection. The incidence of hypoglycemia was low in these trials and was similar to the placebo or control arms. Recently, dose-dependent elevation in liver markers was reported in a pooled analysis of over 8000 patients treated with vildagliptin. Further, investigation is being conducted.

\section{DISCUSSION}

Incretin-based therapies offer an alternative treatment option for T2DM patients by targeting pancreatic $\beta$-cell dysfunction. This review of clinical trial results of three approved incretin-based therapies highlights some of the similarities and differences in the studies. Incretin mimetics and DPP-4 inhibitors reduce AlC and both are 
effective in reducing fasting glucose and PPG, the 2 key components of AlC (19). A recent systematic review of these therapies reinforces these observations and shows that incretin mimetics may have a greater effect on $\mathrm{AlC}$ reduction than DPP-4 inhibitors (73). Amori e cols. (73) further suggested that incretin-based therapies supplement the limited options for targeting postprandial hyperglycemia and should be considered for patients with mild diabetes who are at risk of hypoglycemia and would benefit from losing weight. Both treatment therapies are successful in getting more than $30 \%$ of patients to target AlC values $(\leq 7 \%)$. Only exenatide therapy has been studied in longer term trials; 3-year data from open-label trials show that exenatide is associated with a sustained AlC lowering effect. Moderate improvement in fasting lipids has been observed with both therapies. Incretin mimetics have more gastrointestinal side effects than DPP-4 inhibitors but these subside with continued treatment. DPP-4 inhibitors have an increased risk of respiratory tract infection and headache. A distinguishing feature of exenatide from DPP-4 inhibitors is weight reduction; an important treatment outcome especially for overweight patients with T2DM. Overall, both exenatide and DPP-4 inhibitors have been shown to be effective in improving glycemic control in patients with T2DM. Advances in the investigation of incretin therapies will further improve treatment outcomes for patients with T2DM and help them reach target goals.

Acknowledgements: This review was supported by Eli Lilly and Company. Drs. Davidson and Gross are consultants for Eli Lilly and Company. No honorarium was offered to, or received by, Drs. Davidson and Gross. Dr. Parente is an employee of Eli Lilly and Company working in Medical division with Clinical Research in Diabetes Area. Eli Lilly and Company has a global agreement with Amylin Pharmaceuticals, Inc. to collaborate on the development and commercialization of exenatide. The authors thank Dr. Juliana Helena Abreu Oliveira, Dr. Maria Claudia Jimenez Hamann, and Mr. Justin Northrup fortheircontributions to the development of the manuscript.

\section{REFERENCES}

1. Pan American Health Organization, World Health Organization. 40th Session of the subcommittee on planning and programming of the executive committee. Regional Strategy on an Integrated Approach to the Prevention and Control of Chronic Diseases, including Diet, Physical Activity, and Health. 2006;Provisional Agenda Item 12:1-16.
2. International Diabetes Federation. Diabetes Atlas. 2 ed. 2003.

3. Mainous AG III, Baker R, Koopman RJ, Saxena S, Diaz VA, Everett $\mathrm{CJ}$, et al. Impact of the population at risk of diabetes on projections of diabetes burden in the United States: an epidemic on the way. Diabetologia. 2007;50:934-40.

4. Must A, Spadano J, Coakley EH, Field AE, Colditz G, Dietz WH. The disease burden associated with overweight and obesity. JAMA. 1999;282:1523-9.

5. Blonde L. State of diabetes care in the United States. Am J Manag Care. 2007;13 Suppl 2:S36-S40.

6. Pontiroli AE. Type 2 diabetes mellitus is becoming the most common type of diabetes in school children. Acta Diabetol. 2004;41:85-90

7. Gomes MB, Giannella ND, Mendonca E, Tambascia MA, Fonseca RM, Rea RR, et al. [Nationwide multicenter study on the prevalence of overweight and obesity in type 2 diabetes mellitus in the Brazilian population]. Arq Bras Endocrinol Metabol. 2006:50:136-44.

8. Pan American Health Organization (Alberto Barcelo). Diabetes in the Americas. Epidemiological Bulletin of the Pan American Health Organization. 2001;22:1-3.

9. Kahn SE. The relative contributions of insulin resistance and beta-cell dysfunction to the pathophysiology of Type 2 diabetes. Diabetologia. 2003;46:3-19.

10. Butler $A E$, Janson J, Bonner-Weir S, Ritzel R, Rizza RA, Butler PC. Beta-cell deficit and increased beta-cell apoptosis in humans with type 2 diabetes. Diabetes. 2003;52:102-10.

11. Wajchenberg BL. beta-cell failure in diabetes and preservation by clinical treatment. Endocr Rev. 2007;28:187-218.

12. DeFronzo RA. Pathogenesis of type 2 diabetes: metabolic and molecular implications for identifying diabetes genes. Diabetes Rev. 1997;5:177-269.

13. American College of Endocrinology. American College of Endocrinology Position Statement on the Insulin Resistance Syndrome. Endrocrine Practice. 2003;9:240-52.

14. Unger RH, guilar-Parada E, Muller WA, Eisentraut AM. Studies of pancreatic alpha cell function in normal and diabetic subjects. J Clin Invest. 1970;49:837-48.

15. Muller WA, Faloona GR, guilar-Parada E, Unger RH. Abnorma alpha-cell function in diabetes. Response to carbohydrate and protein ingestion. N Engl J Med. 1970;283:109-15.

16. Pratley $R E$, Weyer $C$. The role of impaired early insulin secretion in the pathogenesis of Type II diabetes mellitus. Diabetologia. 2001;44:929-45.

17. Weyer C, Bogardus C, Mott DM, Pratley RE. The natural history of insulin secretory dysfunction and insulin resistance in the pathogenesis of type 2 diabetes mellitus. J Clin Invest. 1999;104:787-94.

18. Davidson JA. Introductory remarks: diabetes care in America - "a sense of urgency". Endocr Pract. 2006;12 Suppl 1:13-5.

19. Monnier L, Colette C, Dunseath GJ, Owens DR. The loss of postprandial glycemic control precedes stepwise deterioration of fasting with worsening diabetes. Diabetes Care. 2007:30:263-9.

20. Knowler WC, Barrett-Connor E, Fowler SE, Hamman RF, Lachin JM, Walker EA, et al. Reduction in the incidence of type 2 diabetes with lifestyle intervention or metformin. N Engl Med. 2002;346:393-403.

21. Baggio LL, Drucker DJ. Biology of incretins: GLP-1 and GIP Gastroenterology. 2007;132:2131-57. 
22. Cohen A, Horton ES. Progress in the treatment of type 2 diabetes: new pharmacologic approaches to improve glycemic control. Curr Med Res Opin. 2007;23:905-17.

23. Inzucchi SE. Oral antihyperglycemic therapy for type 2 diabetes: scientific review. JAMA. 2002;287:360-72.

24. Hinnen D, Nielsen LL, Waninger A, Kushner P. Incretin mimetics and DPP-IV inhibitors: new paradigms for the treatment of type 2 diabetes. J Am Board Fam Med. 2006;19:612-20.

25. Drucker DJ. The biology of incretin hormones. Cell Metabolism. 2006;3:153-65.

26. Holst JJ, Gromada J. Role of incretin hormones in the regulation of insulin secretion in diabetic and nondiabetic humans. Am J Physiol Endocrinol Metab. 2004;287:E199-E206.

27. Nauck MA, Heimesaat MM, Orskov C, Holst JJ, Ebert R, Creutzfeldt W. Preserved incretin activity of glucagon-like peptide 1 [7-36 amide] but not of synthetic human gastric inhibitory polypeptide in patients with type-2 diabetes mellitus. J Clin Invest. 1993;91:301-7.

28. Zander M, Madsbad S, Madsen JL, Holst JJ. Effect of 6-week course of glucagon-like peptide 1 on glycaemic control, insulin sensitivity, and beta-cell function in type 2 diabetes: a parallel-group study. Lancet. 2002;359:824-30.

29. Drucker DJ, Nauck MA. The incretin system: glucagon-like peptide-1 receptor agonists and dipeptidyl peptidase-4 inhibitors in type 2 diabetes. Lancet. 2006;368:1696-705.

30. Rayner CK, Samsom M, Jones KL, Horowitz M. Relationships of upper gastrointestinal motor and sensory function with glycemic control. Diabetes Care. 2001;24:371-81.

31. Schwartz JG, Green GM, Guan D, McMahan CA, Phillips WT. Rapid gastric emptying of a solid pancake meal in type II diabetic patients. Diabetes Care. 1996;19:468-71.

32. Flint A, Raben A, Astrup A, Holst JJ. Glucagon-like peptide 1 promotes satiety and suppresses energy intake in humans. J Clin Invest. 1998;101:515-20.

33. Naslund E, Barkeling B, King N, Gutniak M, Blundell JE, Holst JJ, et al. Energy intake and appetite are suppressed by glucagon-like peptide-1 (GLP-1) in obese men. Int J Obes Relat Metab Disord. 1999;23:304-11.

34. Gutzwiller JP, Drewe J, Goke B, Schmidt H, Rohrer B, Lareida $\mathrm{J}$, et al. Glucagon-like peptide-1 promotes satiety and reduces food intake in patients with diabetes mellitus type 2. Am J Physiol. 1999;276:R1541-4.

35. Dachicourt N, Serradas P, Bailbe D, Kergoat M, Doare L, Portha B. Glucagon-like peptide-1(7-36)-amide confers glucose sensitivity to previously glucose-incompetent beta-cells in diabetic rats: in vivo and in vitro studies. J Endocrinol. 1997;155:369-76.

36. Farilla L, Hui H, Bertolotto C, Kang E, Bulotta A, Di MU, et al. Glucagon-like peptide-1 promotes islet cell growth and inhibits apoptosis in Zucker diabetic rats. Endocrinology. 2002; 143:4397-408.

37. Kieffer TJ, Mclntosh CH, Pederson RA. Degradation of glucose-dependent insulinotropic polypeptide and truncated glucagon-like peptide 1 in vitro and in vivo by dipeptidyl peptidase IV. Endocrinology. 1995;136:3585-96.

38. Deacon CF, Nauck MA, Toft-Nielsen M, Pridal L, Willms B, Holst JJ. Both subcutaneously and intravenously administered glucagon-like peptide I are rapidly degraded from the $\mathrm{NH}$-terminus in type II diabetic patients and in healthy subjects. Diabetes. 1995;44:1126-31.

39. Mentlein R, Gallwitz B, Schmidt WE. Dipeptidyl-peptidase IV hydrolyses gastric inhibitory polypeptide, glucagon-like peptide-1(7-36)amide, peptide histidine methionine and is respon- sible for their degradation in human serum. Eur J Biochem. 1993;214:829-35.

40. Deacon CF. Therapeutic strategies based on glucagon-like peptide 1. Diabetes. 2004;53:2181-9.

41. Chen YE, Drucker DJ. Tissue-specific expression of unique mRNAs that encode proglucagon-derived peptides or exendin 4 in the lizard. J Biol Chem. 1997;272:4108-15.

42. Stonehouse AH, Holcombe JH, Kendall DM. Management of Type 2 diabetes: the role of incretin mimetics. Expert Opin Pharmacother. 2006;7:2095-105.

43. Riddle MC, Drucker DJ. Emerging therapies mimicking the effects of amylin and glucagon-like peptide 1. Diabetes Care. 2006;29:435-49.

44. DeFronzo RA, Ratner RE, Han J, Kim DD, Fineman MS, Baron AD. Effects of exenatide (exendin-4) on glycemic control and weight over 30 weeks in metformin-treated patients with type 2 diabetes. Diabetes Care. 2005;28:1092-100.

45. Buse JB, Henry RR, Han J, Kim DD, Fineman MS, Baron AD. Effects of exenatide (exendin-4) on glycemic control over 30 weeks in sulfonylurea-treated patients with type 2 diabetes. Diabetes Care. 2004;27:2628-35.

46. Kendall DM, Riddle MC, Rosenstock J, Zhuang D, Kim DD, Fineman MS, et al. Effects of exenatide (exendin-4) on glycemic control over 30 weeks in patients with type 2 diabetes treated with metformin and a sulfonylurea. Diabetes Care. 2005;28:1083-91.

47. Klonoff DC, Buse JB, Nielsen LL, Guan X, Bowlus CL, Holcombe $\mathrm{JH}$, et al. Exenatide effects on diabetes, obesity, cardiovascular risk factors and hepatic biomarkers in patients with type 2 diabetes treated for at least 3 years. Curr Med Res Opin. 2008;24:275.

48. Zinman B, Hoogwerf BJ, Duran GS, Milton DR, Giaconia JM, Kim DD, et al. The effect of adding exenatide to a thiazolidinedione in suboptimally controlled type 2 diabetes: a randomized trial. Ann Intern Med. 2007;146:477-85

49. Heine RJ, Van Gaal LF, Johns D, Mihm MJ, Widel MH, Brodows RG. Exenatide versus insulin glargine in patients with suboptimally controlled type 2 diabetes: a randomized trial. Ann Intern Med. 2005;143:559-69.

50. Nauck MA, Duran S, Kim D, Johns D, Northrup J, Festa A, et al. A comparison of twice-daily exenatide and biphasic insulin aspart in patients with type 2 diabetes who were suboptimally controlled with sulfonylurea and metformin: a non-inferiority study. Diabetologia. 2007;50:259-67.

51. Blonde L, Klein EJ, Han J, Zhang B, Mac SM, Poon TH, et al. Interim analysis of the effects of exenatide treatment on A1C, weight and cardiovascular risk factors over 82 weeks in 314 overweight patients with type 2 diabetes. Diabetes Obes Metab. 2006;8:436-47.

52. Scott R, Wu M, Sanchez M, Stein P. Efficacy and tolerability of the dipeptidyl peptidase-4 inhibitor sitagliptin as monotherapy over 12 weeks in patients with type 2 diabetes. Int $\mathrm{J}$ Clin Pract. 2007;61:171-80.

53. Rosenstock J, Brazg R, Andryuk PJ, Lu K, Stein P. Efficacy and safety of the dipeptidyl peptidase-4 inhibitor sitagliptin added to ongoing pioglitazone therapy in patients with type 2 diabetes: a 24-week, multicenter, randomized, double-blind, placebocontrolled, parallel-group study. Clin Ther. 2006;28:1556-68.

54. Charbonnel B, Karasik A, Liu J, Wu M, Meininger G. Efficacy and safety of the dipeptidyl peptidase-4 inhibitor sitagliptin added to ongoing metformin therapy in patients with type 2 diabetes inadequately controlled with metformin alone. Diabetes Care. 2006;29:2638-43. 
55. Bosi E, Camisasca RP, Collober C, Rochotte E, Garber AJ. Effects of vildagliptin on glucose control over 24 weeks in patients with type 2 diabetes inadequately controlled with metformin. Diabetes Care. 2007;30:890-5.

56. Rosenstock J, Baron MA, Camisasca RP, Cressier F, Couturier A, Dejager S. Efficacy and tolerability of initial combination therapy with vildagliptin and pioglitazone compared with component monotherapy in patients with type 2 diabetes. Diabetes Obes Metab. 2007;9:175-85.

57. Fonseca V, Schweizer A, Albrecht D, Baron MA, Chang I, Dejager S. Addition of vildagliptin to insulin improves glycaemic control in type 2 diabetes. Diabetologia. 2007;50:1148-55.

58. Schweizer A, Couturier A, Foley JE, Dejager S. Comparison between vildagliptin and metformin to sustain reductions in $\mathrm{HbA}(1 \mathrm{c})$ over 1 year in drug-naive patients with Type 2 diabetes. Diabet Med. 2007;24:955-61.

59. Herman GA, Stevens C, Van Dyck K, Bergman A, Yi B, De Smet $M$, et al. Pharmacokinetics and pharmacodynamics of sitagliptin, an inhibitor of dipeptidyl peptidase IV, in healthy subjects: results from two randomized, double-blind, placebo-controlled studies with single oral doses. Clin Pharmacol Ther. 2005;78:675-88.

60. Nonaka K, Kakikawa T, Sato A, Okuyama K, Fujimoto G, Kato $\mathrm{N}$, et al. Efficacy and safety of sitagliptin monotherapy in Japanese patients with type 2 diabetes [Epub]. Diabetes Res Clin Pract. 7 A.D.; [In press].

61. Raz I, Hanefeld M, Xu L, Caria C, Williams-Herman D, Khatami $\mathrm{H}$. Efficacy and safety of the dipeptidyl peptidase-4 inhibitor sitagliptin as monotherapy in patients with type 2 diabetes mellitus. Diabetologia. 2006;49:2564-71.

62. Aschner P, Kipnes MS, Lunceford JK, Sanchez M, Mickel C, Williams-Herman DE. Effect of the dipeptidyl peptidase-4 inhibitor sitagliptin as monotherapy on glycemic control in patients with type 2 diabetes. Diabetes Care. 2006;29:2632-7.

63. Nauck MA, Meininger G, Sheng D, Terranella L, Stein PP. Efficacy and safety of the dipeptidyl peptidase-4 inhibitor, sitagliptin, compared with the sulfonylurea, glipizide, in patients with type 2 diabetes inadequately controlled on metformin alone: a randomized, double-blind, non-inferiority trial. Diabetes Obes Metab. 2007;9:194-205.

64. Mannucci E, Ognibene A, Cremasco F, Bardini G, Mencucci A, Pierazzuoli $E$, et al. Effect of metformin on glucagon-like peptide 1 (GLP-1) and leptin levels in obese nondiabetic subjects. Diabetes Care. 2001;24:489-94.
65. Bergman AJ, Cote J, Yi B, Marbury T, Swan SK, Smith W, et al. Effect of renal insufficiency on the pharmacokinetics of sitagliptin, a dipeptidyl peptidase-4 inhibitor. Diabetes Care. 2007;30:1862-4.

66. Dejager S, Razac S, Foley JE, Schweizer A. Vildagliptin in drug-naive patients with type 2 diabetes: a 24-week, doubleblind, randomized, placebo-controlled, multiple-dose study. Horm Metab Res. 2007;39:218-23.

67. Pi-Sunyer FX, Schweizer A, Mills D, Dejager S. Efficacy and tolerability of vildagliptin monotherapy in drug-naive patients with type 2 diabetes. Diabetes Res Clin Pract. 2007;76:132-8.

68. Pratley RE, Jauffret-Kamel S, Galbreath E, Holmes D. Twelveweek monotherapy with the DPP-4 inhibitor vildagliptin improves glycemic control in subjects with type 2 diabetes. Horm Metab Res. 2006;38:423-8.

69. Ristic S, Byiers S, Foley J, Holmes D. Improved glycaemic control with dipeptidyl peptidase-4 inhibition in patients with type 2 diabetes: vildagliptin (LAF237) dose response. Diabetes Obes Metab. 2005;7:692-8.

70. Ahren B, Gomis R, Standl E, Mills D, Schweizer A. Twelve- and 52-week efficacy of the dipeptidyl peptidase IV inhibitor LAF237 in metformin-treated patients with type 2 diabetes. Diabetes Care. 2004;27:2874-80.

71. Garber AJ, Schweizer A, Baron MA, Rochotte E, Dejager S. Vildagliptin in combination with pioglitazone improves glycaemic control in patients with type 2 diabetes failing thiazolidinedione monotherapy: a randomized, placebo-controlled study. Diabetes Obes Metab. 2007;9:166-74.

72. Rosenstock J, Baron MA, Dejager S, Mills D, Schweizer A. Comparison of vildagliptin and rosiglitazone monotherapy in patients with type 2 diabetes: a 24-week, double-blind, randomized trial. Diabetes Care. 2007;30:217-23.

73. Amori RE, Lau J, Pittas AG. Efficacy and safety of incretin therapy in type 2 diabetes: systematic review and meta-analysis. JAMA. 2007;298:194-206.

\section{Corresponding to:}

Jaime A. Davidson

Department of Medicine, Division of Endocrinology,

University of Texas Southwestern Medical School

Dallas, TX 75230, USA

Email: davidsonmd@sbcglobal.net 